\title{
A centralidade do juízo oral no Sistema Acusatório: uma visão estratégica acerca do caso penal
}

\author{
The oral trial centrality in the Accusatory System: \\ a strategic view of criminal case
}

\section{Raphael Jorge de Castilho Barilli ${ }^{1}$}

Universidade Federal do Rio de Janeiro - Rio de Janeiro/RJ

raphaelbarilli@yahoo.com

http://lattes.cnpq.br/0897287459205783

Dttp://orcid.org/0000-0002-9987-5119

Resumo: O presente artigo visa a debater a questão da oralidade como centro metodológico do sistema acusatório, indicando um formato de administração da justiça pautado no litígio. Para isso, buscou-se apontar que a forma processual escrita, que por muito tempo se colocou como o formato ideal de processo, apresenta-se insuficiente diante da notável influência de elementos diversos, insusceptíveis de apropriação formal, que influenciam no resultado do caso. Neste contexto de litigância oral, é necessário questionar: Há estratégia na apresentação dos elementos no debate oral? Como a noção de estratégia no litígio penal é vista pela comunidade jurídica? Em que momentos do processo essa atuação estratégica deve se implementar? Essas e outras questões serão enfrentadas neste trabalho, que tem como metodologia a investigação teórica de literatura referente a este novo marco teórico, concluindo que a noção de estratégia é uma decorrência natural do novo paradigma processual. Ademais, esta nova forma de pensar o processo é vista como tendência no contexto de reforma processual penal da América Latina ocorrido nas últimas décadas, que busca superar as matrizes inquisitivas do processo, afirmando um sistema acusatório de tendência adversarial verdadeiramente democrático.

1 Mestrando em Direito na Universidade Federal do Rio de Janeiro - UFRJ. Pós-graduado em Direito Público pela Universidade Cândido Mendes - UCAM. Delegado de Polícia do Estado do Rio de Janeiro. 
Palavras-Chave: Direito Processual; Sistema acusatório adversarial; Litigância oral; Estratégia processual.

ABSTRACT: This paper aims to discuss the orality as the methodological center of the accusatory system, indicating an administration of justice format based on the case. To this end, we seek to point out that the written process form, which for a long time has been placed as the ideal process format, is insufficient due to the notable influence of diverse elements, which cannot be formally appropriated, influencing the outcome of the case. In this context of oral litigation, it is necessary to ask: Is there a strategy for presenting the elements in the oral debate? How is the notion of strategy in criminal litigation seen by the law community? At what moments in the process should this strategic action be implemented? These and other issues will be addressed in this exhibition, which has as methodology the theoretical investigation of literature regarding this new framework, concluding that the notion of strategy is a natural consequence of the new procedural paradigm. In addition, this modern thinking process is seen as a trend in the context of criminal procedural reform in Latin America in the last decades, which seeks to overcome the inquisitive nuances of the process, affirming an accusatory system of a truly democratic adversarial tendency.

KeYwords: Procedural law; adversarial accusatory system; Oral litigation; Procedural strategy.

SUMÁRIO: Introdução; 1. O paradigma processual da gestão do conflito jurídico-penal, 2. Gestão de conflito e o tema da verdade no processo, 3. A centralidade do juízo oral no sistema acusatório, 4. A incorporação da visão estratégica no processo penal; Considerações finais; Referências bibliográficas.

\section{INTRODUÇÃo}

"O que não está nos autos não está no mundo" é um conhecido brocado do Direito que representa uma busca incessante pela superioridade da razão, refletindo a postura científica positivista dominante no início do século passado, preocupada com a sistematização e regulação 
dos fenômenos sociais de forma objetiva tal como as ciências da natureza. ${ }^{2}$ É neste contexto que todo aparato de resolução de conflitos do Estado se organiza, tendo a burocratização e a escrituração do processo como forma de assegurar que a resolução das causas fosse pautada acima de tudo pela razão, excluindo dos autos, que seria o mundo do processo, qualquer coisa que não fosse objetivamente considerada. ${ }^{3}$

Todavia, não é difícil compreender a impossibilidade que um conjunto de papéis terá em expressar todas as particularidades que envolvem um conflito, especialmente um litígio penal. Desse modo, as partes envolvidas no processo frequentemente se utilizam de elementos que não são escritos para desenvolver suas argumentações e conclusões, como por exemplo a postura do réu em audiência, se demonstra ou não emoção, ou o estereótipo de um jurado na formação do conselho de sentença, e isto reflete na decisão do juiz, que, por mais dedicado que seja, jamais conseguirá expressar todo o seu convencimento em uma sentença, permanecendo sempre uma parcela no que se convencionou chamar de convicção íntima. ${ }^{4}$

É neste sentido que a oralidade ganha extrema relevância no sistema acusatório, não como mera característica do processo, mas sim como verdadeiro centro metodológico que ordena e condiciona a atuação processual. Ou seja, uma vez que a resolução do conflito será pautada pelo diálogo entre as partes, sendo certo que essa interação traz elementos que são insusceptíveis de plena escrituração nos autos, é necessária a afirmação de um espaço eficaz que proporcione, além da compreensão da causa, o debate acerca dos fatos e provas produzidas. ${ }^{5}$

Apesar da importância do juízo oral, quando observada na prática a forma com que o processo é desenvolvido nos tribunais, constata-se uma séria resistência nesse sentido, ${ }^{6}$ o que produz um déficit de oralidade,

2 WEBER, Max. Metodologia das Ciências Sociais. São Paulo, Campinas: Unicamp, 1993. p. 109.

3 PRADO, Geraldo. Sistema Acusatório: A conformidade Constitucional das Leis Processuais Penais. Rio de Janeiro: Lumen Juris, 2006. p. 157.

4 HASSEMER, Winfried. Fundamentos del Derecho Penal. Barcelona: Bosh, 1984. p. 145.

5 PRADO, Geraldo. Ob. cit., p. 155.

6 CHOUKR, Fauzi H. Iniciação ao processo penal. Florianópolis: Empório do Direito, 2017. p. 348. 
resquício da mentalidade inquisitiva que prima pela busca da verdade através da escrituração. ${ }^{7}$ Nesta esteira, cada vez mais as audiências se comprimem em pautas superlotadas e que se realizam de forma açodada; dividem-se as audiências em conjuntos de atos, perdendo-se a unidade e imediação com o julgador da causa; sustenta-se cada vez mais a desnecessidade da presença física do réu em virtude dos custos e riscos inerentes ao transporte de presos; limita-se o contato da defesa técnica com o acusado a alguns poucos minutos entre outras mazelas que evidenciam que o nosso sistema de justiça criminal está muito longe da essência acusatória pretendida.

É neste sentido que buscamos afirmar a oralidade como verdadeiro centro metodológico do processo, desafiando a estrutura atualmente concebida. Para isso, será necessário tratar do paradigma processual da gestão de conflitos que ressalta a resolução do conflito de interesses como fim principal do processo, de modo que todos os seus institutos acabam por se conformar a essa nova realidade. $O$ tratamento da verdade ganha contornos especiais sob essa ótica, passando de uma concepção filosófica de verdade material para uma acepção formal, que assume a sua relatividade.

Ademais, a atuação em um processo pautado por um juízo oral demanda um comportamento diferenciado das partes que necessariamente passa pela compreensão e definição de uma estratégia de como apresentar os fatos, as evidências e demais elementos de convicção. Desta maneira, surgem alguns questionamentos que precisam ser enfrentados: Como é vista a atuação estratégica nos litígios penais? Promover a estratégia é diminuir o compromisso com a verdade? Somente no juízo oral é que se desenvolve a atuação estratégica ou também em outros momentos processuais?

Não se pretende esgotar o tema da importância do juízo oral e a consequente atuação estratégica no processo, visto que se trata de um objeto muito rico e instigante. Todavia, urge a necessidade de se

7 BINDER, Alberto. Fundamentos para a reforma da justiça penal. In: GOSTINSK, Aline; GONZÁLEZ POSTIGO, Leonel; PRADO, Geraldo (org.). Coleção Reflexões sobre a reforma da justiça penal. Florianópolis: Empório do Direito, 2017., p. 33. 
debater as bases do processo penal e, em especial do sistema acusatório, para além da velha temática dos conceitos e características, buscando, assim, reforçar o princípio acusatório e, acima de tudo, contribuir com o fortalecimento do pensamento reformista no processo penal que vem se operando paulatinamente na América Latina.

\section{O paradigma processual da Gestão do conflito JURÍdico-PENAL}

O processo penal há muito tempo é visto como um meio para a imposição de uma sanção, se colocando como o caminho necessário que condiciona o poder punitivo à observância de uma série de regras que compõem o devido processo penal. Desta forma, a instituição do processo como garantia visa a concebê-lo como o único meio legítimo para a satisfação da pretensão acusatória e a imposição de pena, conformando todo o tratamento do processo a este fim. ${ }^{8}$

Contudo, o erro não está em tratar o processo como marco para imposição de pena, mas em considerá-lo como a única finalidade, ou simplesmente a mais importante. ${ }^{9}$ Na realidade, a utilização do processo centrada no estrito cumprimento da lei acaba por esquecer que neste se encerra, além do conflito em relação à sociedade, objeto de consideração pública, um outro conflito de natureza particular entre a vítima e o autor do fato. ${ }^{10}$

Dessa maneira, o processo possui como finalidade também a resolução do conflito, pressupondo que o delito, como qualquer problema jurídico, gera um conflito de interesses entre as partes envolvidas. De um lado observa-se a vítima com interesse de que se imponha uma sanção correspondente ao fato e, especialmente, que se reparem os danos e prejuízos sofridos, e do outro lado estará o suposto autor do fato, que terá interesse em ser declarado inocente ou mesmo receber uma punição atenuada. ${ }^{11}$

\footnotetext{
8 LOPES JR., Aury. Direito Processual Penal. São Paulo: Saraiva, 2014. p.35.

9 BINDER, Alberto. Ob. cit., p.13.

10 BENAVENTE CHORRES, Hesbert. La aplicación de la teoría del caso y la teoría del delito en el proceso penal acusatorio. Barcelona: Bosh, 2011. p. 32.

11 Ibidem.
} 
É neste sentido que se propõe uma mudança de mentalidade processual, pautada pelo paradigma processual da gestão de conflitos, que implica ver o delito como um conflito de interesses, convocando, desta forma, as partes a atuarem no processo, ficando o juiz encarregado do controle e julgamento final. ${ }^{12}$

Em verdade, sob a perspectiva punitivista, réu e vítima sempre tiveram uma posição diminuída diante do litígio jurídico-penal, funcionando basicamente como fonte de prova, uma vez que esta concepção, formada majoritariamente sob bases inquisitivas e autoritárias, tinha seu compromisso firmado com a produção da verdade histórica, o que levava à ênfase das instituições e dos meios probatórios, transformando o processo basicamente em um instrumento público de verificação da verdade. ${ }^{13}$ Desta forma, o processo se desenvolvia longe das partes do conflito, com iniciativas oficiosas, correndo através de procedimentos sigilosos e escriturais, onde qualquer debate ou diálogo era meramente acidental, e na maioria das vezes evitado, já que poderia representar uma distração desnecessária, tornando sem sentido o conceito de parte. ${ }^{14}$

E o principal argumento para instauração desse modelo foi justamente a insuficiência da atividade das partes, que levava a uma suposta impunidade. ${ }^{15}$ Em razão disso, pretendeu-se o desenvolvimento do processo sob a perspectiva epistemológica inquisitiva a pretexto de ser mais eficiente em relação à produção da verdade, pois pautava-se em uma suposta superioridade moral do juiz, ${ }^{16}$ que seria o sujeito desinteressado e mais capaz de, gerindo a iniciativa probatória, desvendar os fatos chegando o mais próximo possível da verdade real.

12 BINDER, Alberto. Prólogo. In: MORENO HOLMAN, Leonardo. Teoría del caso. Buenos Aires: Didot, 2012. p.15.

13 LANGER, Máximo. La dictomía acusatorio-inquisitivo y la importación de mecanismos procesales de la tradición jurídica anglosajona, In: MAIER, Julio B. J. (org.). El procedimento abreviado. Buenos Aires: Del Puerto, 2005. p. 117

14 COUTINHO, Jacinto Nelson de Miranda. O Papel do Novo Juiz no Processo Penal. In: COUTINHO, Jacinto Nelson de Miranda (org.). Crítica à Teoria Geral do Processo Penal. Rio de Janeiro: Renovar, 2001. p. 23.

15 LOPES JR., Aury. Ob. Cit., p. 97.

16 BINDER, Alberto. Ob. cit,, p.14. 
Todavia, essa formulação se pautava em considerações filosóficas e teóricas equivocadas, levando à inconsistência desse modelo processual sob sua forma pura. Dentre elas, destaca-se, portanto, o conceito de verdade histórica absoluta como algo possível e a noção de superioridade moral do juiz. Não se pretende esgotar o tema nessa breve exposição, mas tão somente enunciar os seus principais aspectos, reforçando as conclusões que serão propostas.

Em primeiro lugar, o conceito de verdade tratado pela epistemologia inquisitiva pautava-se em uma verdade substancial ou material, ensejando a noção de verdade absoluta que fosse igualmente compreendida em relação aos sujeitos envolvidos. Desta forma, por ser um procedimento técnico e objetivo, entendia-se que a missão do processo seria encontrar esta verdade histórica ocorrida no passado, e para isto, dispensava-se a aplicação de regras e limites processuais. ${ }^{17}$

Contudo, esta noção unívoca de verdade absoluta, certa ou objetiva não é possível, representando, de fato, um ideal inalcançável. Nem mesmo as teorias científicas de outras áreas mais objetivas do conhecimento humano possibilitam concluir que o resultado da atividade é verdadeiro de modo a garantir a inexistência de proposições falsas, visto que uma tendência inafastável da evolução científica é a superação por teorias ou hipóteses contraditórias que problematizarão as conclusões anteriores de modo a torná-las ultrapassadas. ${ }^{18}$

É como ensina Taruffo:

De fato, a ideia de uma verdade absoluta pode ser uma hipótese abstrata em um contexto filosófico amplo; entretanto, não se pode sustentar racionalmente que uma verdade absoluta possa ou deva ser estabelecida em qualquer domínio do conhecimento humano, tampouco no contexto judicial. Mesmo ciências rígidas como as físicas e as matemáticas não pretendem ser capazes de alcançar verdades absolutas; de fato, a ideia de uma verdade absoluta parece pertencer somente aos domínios da religião e da metafísica. Em verdade, em todo contexto do conhecimento científico e empírico,

17 FERRAJOLI, Luigi. Direito e Razão: Teoria do garantismo penal. São Paulo: Revista dos Tribunais, 2002. p. 37. 
incluído o dos processos judiciais, a verdade é relativa. Na melhor das hipóteses, a ideia geral da verdade pode ser concebida como uma espécie de «ideal regulador», ou seja, como um ponto de referência teórico que se deve seguir a fim de orientar a empresa do conhecimento na experiência real do mundo. ${ }^{19}$

Deste modo, diante da impossibilidade da noção de verdade como algo absoluto, ocorre uma notável degeneração das proposições em juízos de valor, amplamente arbitrários, gerando um decisionismo não cognitivo, mas sim potestativo por parte do juiz. Ou seja, a decisão, ao invés de se pautar em uma verdade empírica, baseada em fatos e provas, controlável intersubjetivamente pelas partes por meio de standards objetivos, ${ }^{20}$ passa a ser pautada no convencimento íntimo e subjetivo do juiz, frequentemente fazendo alusão a elementos abstratos como a qualidade pessoal do réu e sua periculosidade social. ${ }^{21}$

Aliado a isto, diversas violações a direitos eram observadas em nome dessa busca da verdade, tendo em vista que a presença de regras e controles rígidos representava obstáculo ao fim processual. ${ }^{22}$ Nesse sentido, o processo transformava-se em verdadeira inquisição, sendo a prova penal gerida basicamente por decisionismos, levando à diversas arbitrariedades em nome do resultado do processo, o que levou o sistema inquisitivo a ser conhecido pela sua expressiva faceta de violação a direitos.

Em segundo lugar, uma outra concepção dominante era o fato de que se creditava ao juiz uma nítida superioridade moral, considerando-o o sujeito mais capacitado para alcançar a verdade histórica. ${ }^{23} \mathrm{E}$ isto se dava basicamente pela crença de que o juiz, por ser um representante do Estado, seria um sujeito desinteressado em relação ao conflito, livre de qualquer relação subjetiva com o caso, devendo, portanto, gerir as provas longe do contraditório para alcançar a verdade.

19 TARUFFO, Michele. A prova. São Paulo: Marcial Pons, 2014. p. 25-26.

20 KNIJNIK, Danilo. Prova nos juízos cível, penal e tributário. Rio de Janeiro: Forense, 2007. p. 16.

21 FERRAJOLI, Luigi. Ob. Cit., p. 37.

22 KHALED, Salah H. A busca da verdade no processo penal para além da ambição inquisitorial. Minas Gerais: Letramento: Casa do Direito, 2016. p. 73.

23 COUTINHO, Jacinto Nelson de Miranda. Ob. cit., p. 23 
Todavia, esta imagem do juiz como investigador imparcial é absolutamente ingênua, pois, como em qualquer investigação empírica, a atuação do juiz será sempre seletiva, orientada por pontos de vista e interesses morais, políticos e éticos do próprio investigador, levando-o a analisar determinadas hipóteses em detrimento de outras. ${ }^{24}$ Basta que pensemos no historiador que analisa os fatos segundo os seus interesses historiográficos e, por mais que utilize um determinado critério objetivo de seleção, certamente acabará por privilegiar determinadas fontes históricas em detrimento de outras, chegando até mesmo a ignorar algumas, e somente a sua honestidade científica é que será capaz de formalizar essa parcialidade. ${ }^{25}$

Dessa forma, é impossível conceber o juiz como um investigador imparcial dos fatos, pois a gestão das provas será sempre precedida de considerações psicológicas que conformarão a sua atuação e, consequentemente, implicarão no resultado do seu trabalho. ${ }^{26}$

Torna-se ainda mais perigosa a visão de imparcialidade na investigação dos fatos no processo judicial, visto que, diferentemente da história e outras ciências que são vocacionadas à superação das conclusões por trabalhos futuros, o trabalho do juiz é direcionado à imutabilidade, 0 que o torna um investigador exclusivo, diminuindo a sua capacidade de correção. Neste sentido, ensina Luigi Ferrajoli ao afirmar que "em decorrência disso, o erro judiciário, diversamente do erro historiográfico ou científico, jamais é fecundo, pois suas consequências são em grande parte irreparáveis, especialmente se são produzidas em prejuízo do acusado." ${ }^{27}$

Sendo assim, o principal elemento que induzia a uma suposta superioridade moral do juiz para a investigação da verdade no processo cai por terra na medida em que se reconhece a inexistência de neutralidade na investigação empírica.

Nem mesmo sob a perspectiva institucional a ideia de superioridade do juiz seria viável. Isto porque a concepção do Direito pautado pela teoria interpretativa de Dworkin, que rompia com o positivismo,

\footnotetext{
24 FERRAJOLI, Luigi. Ob. Cit., p. 47.

25 HABERMAS, Junger. Conhecimento e interesse. Rio de Janeiro: Zahar, 1982. p. 216.

26 PRADO, Geraldo. Ob. cit., p. 137.

27 FERRAJOLI, Luigi. Ob. Cit., p. 48.
} 
depositando no juiz seu centro metodológico, ${ }^{28}$ vem paulatinamente cedendo espaço a uma visão institucional que problematiza e questiona essa supremacia.

A visão interpretativa buscou agregar uma dimensão justificadora ao Direito, rompendo com a tradição descritiva do positivismo, para quem o Direito equivaleria à norma. Na visão de Dworkin, o Direito nasce de um processo de construção e justificação, propondo uma teoria mais completa, onde o juiz deixa de ser um mero aplicador para ser uma ferramenta de construção do Direito. ${ }^{29}$

Todavia, essa concepção se utiliza de uma visão romanceada do juiz, que Dworkin cunhou como juiz Hércules, como sendo o ideal de juiz a ser perseguido. Na verdade, essa visão interpretativa não assume uma dimensão prática consequencialista, que busque analisar questões institucionais relevantes para o processo decisório, como as capacidades institucionais dos agentes envolvidos, a realidade das instituições na prática entre outros, limitando-se a formar uma teoria do Direito ideal. ${ }^{30}$

É por isso que surgem, especialmente no Direito estadunidense, teorias institucionais que partem de uma perspectiva consequencialista do Direito, ${ }^{31}$ propondo que em determinadas questões o Judiciário apresente certa deferência em relação a outros agentes institucionais quando estes apresentarem melhores condições de decidir, independentemente do que seria o melhor na teoria, como, por exemplo, agências reguladoras diante de questões técnicas. Não se está aqui buscando uma visão eminentemente pragmática, mas sim reforçando a ideia de que visões idealizadas das instituições do ponto de vista normativo não têm espaço na construção de um processo penal como um saber prático. ${ }^{32}$

28 DWORKIN, Ronald. O império do direito. São Paulo: Martins Fontes, 1999. p. 109.

29 SENS, Sheila C. da S. A teoria interpretativa de Dworkin: Um modelo construtivo. Revista da Faculdade Mineira de Direito. v. 16, n. 31, p.119-147, 2013. p. 4.

30 VERMEULE, Adrian. Judging under uncertainty: An institucional theory of legal interpretation. London: Harvard University Press, 2006. p. 16.

31 Ibidem., p. 63.

32 É neste sentido que alerta Binder: "O processo penal não pode ser visto somente como um conjunto de normas que regulam os atos processuais ou as faculdades das partes. (...) Nesse sentido, a justiça penal é um 'universo de 
Portanto, com essa breve exposição pretendeu-se demonstrar que o paradigma processual punitivo, concebido sob uma perspectiva inquisitiva, era pautado, dentre vários, em dois argumentos filosóficos que não se sustentam, quais sejam a concepção de verdade substancial absoluta e a superioridade moral do juiz. Entretanto, diante de todas essas críticas deve surgir o seguinte questionamento: Devemos pensar em deslegitimar a função do Estado de aplicação da pena? A resposta necessariamente deve ser não, visto que o processo representa importante limitação tanto ao Estado, quanto aos particulares, inibindo a imposição de pena de forma arbitrária.

Todavia o que se deve pensar é na utilização mais racional para o processo e sua função sancionadora, que passa justamente pelo perigo latente de se considerar como a única ou a mais importante finalidade do processo. Como visto, essa visão punitivista tende a uma apologia do sistema inquisitivo, levando, entre outras coisas, a uma visão deturpada do conceito de verdade e à centralidade da figura do juiz. E isto sem mencionar que essa racionalidade punitiva tende a justificar qualquer tipo de processo onde a falta de respeito às garantias e aos direitos é a tônica dos sistemas de justiça penal dos Estados autoritários. ${ }^{33}$

Diante disso, exsurge o paradigma da gestão de conflitos pautado na segunda finalidade do processo, que é justamente resolução do conflito jurídico entre as partes. O delito, como qualquer problema jurídico, gera interesses entre as partes envolvidas, que devem assumir um papel de destaque no desenvolvimento do feito, de modo que qualquer utilização minimamente racional do processo deve passar pela afirmação do debate entre as partes, que são os maiores interessados na resolução da causa. ${ }^{34}$

práticas', orientado por sistemas normativos complexos. Essas práticas constituem os atos dos distintos sujeitos que participam do processo penal. (...) Não se trata de renunciar ao comprometimento central de construir um saber sobre o sentido das normas, mas sim de ter em conta de um modo amplo sua capacidade de gerar ou modificar práticas. Do que se trata é construir um saber prático com capacidade de influir sobre o mundo real da justiça penal (...)." (BINDER, Alberto. Derecho procesal penal. Buenos Aires: Ad-Hoc, 2013, p. 38-40) (tradução livre).

33 BENAVENTE CHORRES, Hesbert. Ob. Cit., p. 30.

34 Ibidem. 
Enquanto a concepção punitivista ignorava o debate, ${ }^{35}$ centrando na figura do juiz todas as suas expectativas e anseios, a concepção da gestão de conflitos, ao contrário, convoca as partes para atuarem de forma dialética no processo, com respeito aos direitos e garantias fundamentais, contribuindo para a solução da causa. ${ }^{36}$

Note-se que a concepção da gestão de conflitos não ignora que o processo é destinado à aplicação de uma pena prevista em lei, nem busca excluir a atuação do Ministério Público como titular principal da persecução penal, entregando às partes a condução exclusiva do processo como uma espécie de retorno à sanção como vingança privada. ${ }^{37} \mathrm{O}$ que se pretende, pois, é afirmar o conflito como elemento central do delito e, por sua vez, do processo, o que enseja uma maior participação das partes envolvidas, que ostentarão um papel principal devendo construir, argumentar e fundamentar seus interesses, expectativas e pretensões, agregando elementos essenciais para que o juiz consiga julgar o caso. ${ }^{38}$

Essa noção acabará por impor uma maior coordenação entre Ministério Público ${ }^{39}$ e vítima, já que seus interesses deverão ser consi-

35 GOMES FILHO, Antônio Magalhães. Prefácio. In: MALAN, Digo R. Direito ao confronto no processo penal. Rio de Janeiro: Lumen Juris, 2009. p. xiii.

36 CAVISE, Leonard L. The transition from the inquisitorial to the accusatorial system of trial procedure: Why some Latin American lawyers hesitate. Disponível em: <http://biblioteca.cejamericas.org/bitstream/handle/2015/3622/ cavise.pdf?sequence=1\&isAllowed=y>. Acesso em: 20 jan. 2018. p. 45 .

37 A noção de processo penal como categoria autônoma pautado por critérios de justiça passa a interessar fortemente quando do fortalecimento do Estado na imposição da pena pública, desligando a vítima paulatinamente do manejo desta, transferindo essa atividade a um juiz imparcial. Como ensina Aury Lopes Jr., "a titularidade do direito de penar por parte do Estado surge no momento em que se suprime a vingança privada e se implantam os critérios de justiça. (...) À medida em que o Estado se fortalece, consciente dos perigos que encerra a autodefesa, assumirá o monopólio da justiça, produzindo-se não só a revisão da natureza contratual do processo, senão também a proibição expressa para os indivíduos de tomar a justiça por suas próprias mãos.” (LOPES JR., Aury. Ob. Cit., p. 38). BENAVENTE CHORRES, Hesbert. Ob. Cit.,p. 33.

39 Para este modelo, é essencial que o Ministério Público abandone a posição chamada de tradicional, forjada sob critérios inquisitivos, com uma suposta posição imparcial de controle da lei e da legalidade, agregada a funções consultivas, atuando de maneira uniforme em todos os casos, para adotar efetivamente uma posição de parte. Neste sentido, será fundamental a 
derados na tomada de decisões acerca da persecução e sua participação valorizada ao longo de todo o processo. Ademais, levará, ao lado da pretensão de sanção, a uma maior aplicação do princípio da oportunidade e de saídas alternativas como a conciliação e acordos reparatórios que possuem assento tanto em relação à pretensão de reparação, quanto em princípios de política criminal relacionados à seleção de casos, ${ }^{40}$ justiça restaurativa e solução consensual do conflito. ${ }^{41}$

Esta mudança de paradigma permite a consagração de um sistema verdadeiramente acusatório, tão mitigado quando pensado à luz da concepção punitivista, já que o objetivo era punir, sem importar como. Neste sentido, a acusatoriedade, centrada na separação das funções de acusar e julgar, ${ }^{42}$ representava verdadeiro empecilho à função punitiva. Neste novo modelo acusatório, marcado pela tendência adversarial, o juiz identifica as expectativas das partes, que terão o papel de argumentar e fundamentar seus interesses e pretensões, devendo o juiz controlar o debate, vindo a emitir ao final uma decisão fundada no Direito. ${ }^{43}$

reconsideração das funções da persecução penal, promovendo uma maior integração com a polícia investigativa, decidindo de forma estratégica os casos que em serão concentrados os esforços, além de investir no mister de litigância processual. Sobre isso: DUCE, Mauricio; RIEGO, Cristián. Desafios del Ministério Público fiscal en América Latina. Santiago de Chile: Centro de Estudios de Justicia de las Américas CEJA, 2005, p. 62-63.

"A razão central para esta mudança foi o reconhecimento de que os recursos materiais, humanos e financeiros (sempre limitados) não permitem processar e julgar com eficiência todos os casos. Diante disso, sob a ficção do princípio da legalidade processual, produziu-se uma seletividade natural das agências policiais, que faziam um filtro, mas sem critérios nem controle, pegando as obras mais toscas e de simples resolução como uma lógica de sobrevivência burocrática. É por isso que um processo acusatório se constrói sobre esta realidade e sugere a necessidade de dar um tratamento particular e distinto aos casos que permitam algum grau de acordo entre as partes. E, consequentemente, alocar os recursos do sistema aos casos cuja solução é obtida através da existência de juízo oral e público.” (RUA, Gonzalo; GONZALEZ, Leonel. As saídas alternativas ao processo penal na América Latina. Uma visão de sua regulamentação e propostas de mudança. Revista Sistemas Judiciales, Santiago de Chile, a. 16, n. 20. 2017, p. 99-124, p. 101-102) (tradução livre).

41 BENAVENTE CHORRES, Hesbert. Ob. Cit. p. 33.

42 BADARÓ, Gustavo H. Processo Penal. São Paulo: Revista dos Tribunais, 2017, p. 98.

43 BENAVENTE CHORRES, Hesbert. Ibidem. 
Neste momento surge um questionamento importante para fins de adequação desta nova concepção: A estrutura adversarial permite que as partes afirmem qualquer tipo de versão, ainda que desligada dos fatos e provas? Ou seja, qual o critério epistêmico para conhecimento do conjunto probatório por parte do juiz? É isto que será enfrentado na sequência.

\section{Gestão de conflito e o tema da verdade no processo}

O modelo processual centrado sob a perspectiva do conflito tem no debate entre as partes o principal elemento para a solução da causa. Ou seja, caberá às partes promover os seus interesses e expectativas ao longo do processo, apresentando as provas e argumentações correspondentes, dando condições para que o juiz emita uma decisão ao final.

Entretanto, isso não representa uma permissão para que se promova considerações absurdas a respeito dos fatos, ou mesmo que se legitime a atuação desleal de tentar ludibriar o juiz com argumentos incompatíveis. Há, pois, uma vinculação do juiz ao substrato fático, estando impedido de julgar de forma dissociada da verdade, devendo, portanto, identificar as expectativas normativas das partes e, diante do diálogo, decidir com base no Direito. ${ }^{44}$

E isto se dá em razão da utilização da categoria de resolução de conflito pautada no objetivismo crítico ${ }^{45}$ que postula uma noção cognoscitivista da prova. Para este modelo epistemológico, a prova é concebida como um instrumento de conhecimento, direcionada à verificação da verdade sobre os fatos controvertidos, e uma fonte de conhecimento, que, por ser indutivo e estar institucionalizado, sofre sérias limitações, permitindo um conhecimento meramente provável. ${ }^{46}$

44 Ibidem.

45 GONZÁLEZ LAGIER, Daniel. Quaestio facti: Ensayos sobre prueba, causalidad y acción. Disponível em: <http://www.academia.edu/24429680/Quaestio_facti_Ensayos_sobre_prueba_causalidad_y_acci\%C3\%B3n>. Acessado em: 20 jan. 2018. p, 10.

46 GASCÓN ABELLÁN, Marina. La motivación de la prueba. In: BETEGÓN, Jerónimo, DE PÁRAMO, Juan Ramón, LAPORTA, Francisco J., SANCHÍS, Luis Prieto (org). Constituición y derechos fundamentales. Madrid: Secretaría General Técnica. Centro de estudios políticos y constitucionales. 2004, p. 773-794. p. 780. 
Ou seja, o status de relatividade que se obtém através de investigações empíricas conduz à conclusão de que o processo só permite realizar um juízo aproximado do valor de verdade em relação ao resultado produzido, em termos de probabilidade. Todavia, isto não quer dizer que as conclusões assumidas pelo juiz não possuem um valor nesse sentido, já que as provas, segundo este modelo cognicitivista, permitem o conhecimento da verdade, embora limitado. ${ }^{47}$

Sendo assim, reputa-se como objetivo do processo alcançar a verdade através do conhecimento, ainda que limitado, dos fatos, utilizando-se, para tanto, dos meios de prova disponíveis. Desta forma, se coloca como condição de justiça da decisão o fato de estar pautada em um juízo acerca da verdade dos fatos, embora se reconheça a limitação deste conjunto de elementos empíricos. ${ }^{48}$

Em contraposição a esse modelo há a epistemologia construtivista, que entende que a objetividade do conhecimento está relacionada a esquemas de pensamentos e juízos de valor, ou seja, a verdade, além de inacessível, estará sempre relacionada a contextos. Desta maneira, qualquer pretensão de averiguação da verdade sucumbe diante da função de resolução de conflito, não sendo necessário que a prova se oriente a averiguar a verdade, devendo ser utilizada como fonte de persuasão, orientando o julgador de modo a obter uma decisão favorável. ${ }^{49}$

Essa teoria indicada se vincula primariamente ao sistema do adversarial system, cuja principal finalidade do processo é justamente a resolução do conflito, entendendo-se a prova não como instrumento de verificação da verdade, mas sim como meio de persuasão. Ou seja, tende-se a pensar que em um processo de partes, a prova é entendida como meio de persuadir, compreendendo-se em termos práticos como instrumento tendente a obter uma decisão favorável. ${ }^{50}$

47 BENAVENTE CHORRES, Hesbert. La construcción de los interrogatorios desde la teoría del caso. Barcelona: Bosh Editor, 2015. p. 22.

48 BENAVENTE CHORRES, Hesbert. La aplicación de la teoría del caso y la teoría del delito en el proceso penal acusatorio. Barcelona: Bosh Editor, 2011. p. 32., p. 23.

49 TARUFFO, Michele. Modelli di prova e di procedimento probatorio. Rivista di Diritto Processuale, Padova, v.2, XLV, p. 420-448, 1990. p. 421.

50 Ibidem. 
Nesse sentido, estabelece-se uma relação intuitiva entre verdade e sistema inquisitivo de um lado, e resolução de conflitos e sistema adversarial de outro. ${ }^{51}$ Assim, no primeiro haveria o compromisso com a verdade, porém com vistas à imposição de uma pena, desenvolvendo-se de forma autoritária, enquanto que no segundo haveria a busca na resolução do conflito de forma dialética, todavia pautada na persuasão, com a possibilidade de decisões desligadas da verdade.

Entretanto, a relação que se quis estabelecer é equivocada quando colocada em termos absolutos, dando a entender que em um processo pautado na resolução de conflitos seria impassível de adoção de critérios de verdade formal, quando de fato não há qualquer empecilho neste sentido. É como ensina Benavente Chorres ao apontar que "a suposta tensão indissolúvel entre averiguar a verdade e resolver o conflito está mal colocada (...). Neste sentido, é perfeitamente plausível falar da provisão de resoluções baseadas em determinações tendencialmente verdadeiras em torno dos fatos". ${ }^{2}$

A noção de verdade não deve ser transformada em algo pejorativo pelo simples fato de se associar primariamente à concepção inquisitiva, justamente porque esta correlação não é peremptória. Muito pelo contrário, a ideia de verdade, ainda que limitada, subjaz uma questão de justiça da decisão, devendo estar presente no processo sob a perspectiva do conflito. Como ensina Taruffo, "uma justiça não arbitrária deve basear-se em alguma medida na verdade, isto é, em juízos sujeitos à verificação empírica; (...) uma justiça sem verdade equivale a um sistema de arbitrariedade em que não existem garantias substanciais nem processuais." ${ }^{53}$

Sendo assim, o paradigma da gestão do conflito promove uma visão acusatória com tendência adversarial, pois enxerga o processo diante da função de resolução do conflito, convocando as partes para que defendam em juízo os seus interesses, permanecendo o juiz com uma função de árbitro do debate e julgador final. Todavia, a versão que as partes apresentarão no diálogo não poderá ser completamente dissociada de credibilidade segundo os fatos e provas, visto que o modelo de conhecimento da prova

51 TARUFFO, Michele. La prueba de los hechos. Madrid: Editorial Trota, 2002. p. 42.

52 BENAVENTE CHORRES, Hesbert. La construcción de los interrogatorios desde la teoría del caso. Barcelona: Bosh Editor, 2015, p. 23 (tradução livre).

53 TARUFFO, Michele. Ob. Cit., p. 69 (tradução livre). 
não se pauta pela simples persuasão, mas sim pelo conhecimento objetivista crítico que busca tratar a prova como fonte de conhecimento de uma verdade provável. Desta maneira, é condição de justiça da decisão que esta esteja pautada em uma verdade formal faticamente verificável.

Estabelecidas tais premissas, cumpre-nos tratar agora da forma com que o debate deverá ser desenvolvido ao longo do processo. Uma vez que a resolução do conflito passa pelo diálogo, é necessário que o processo ofereça um ambiente favorável, que garanta a interlocução de forma efetiva, e somente o juízo oral será suficiente para permitir esta interação.

\section{A centralidade do juízo oral no sistema acusatório}

Por muito tempo a doutrina concebia como sistema acusatório todo sistema processual que enxergasse o juiz como um sujeito passivo rigidamente separado das partes e o julgamento como um debate paritário, iniciado pela acusação, que teria o ônus da prova, desenvolvida com a defesa mediante um contraditório público e oral e solucionado pelo juiz, com base em sua livre convicção. ${ }^{54}$ Dessa forma, a grande preocupação desse sistema processual seria em resguardar a imparcialidade do juiz, afastando-o de qualquer atividade das partes, em especial da gestão da prova, mantendo-se uma equidistância como condição de julgamento. ${ }^{55}$

Entretanto, conforme deixou-se transparecer na introdução deste trabalho, a oralidade não se apresenta como simples característica do sistema acusatório, que recomendaria o predomínio de atos processuais na forma oral, mas sim representa o verdadeiro centro metodológico do processo que condiciona toda a atuação processual, desde a fase de investigação até o julgamento recursal. É neste sentido que se afirma que o princípio acusatório não sobrevive em modelos de justiça criminal pautados pela escrituração, ${ }^{56}$ justamente porque a oralidade não é uma opção, mas sim a própria base da estrutura processual. ${ }^{57}$

${ }^{54}$ FERRAJOLI, Luigi. Ob. Cit., p. 450.

55 LOPES JR., Aury. Ob. Cit., p. 96.

56 PRADO, Geraldo. Ob. cit., p. 153.

57 “(...) Todos os modelos acusatórios comparados insistem em instalar o juízo oral como etapa central do procedimento penal, negando valor probatório 
Ora, se a resolução do conflito é pautada no diálogo entre as partes, somente em um debate oral é que se observará a sua máxima potencialidade e isso não é muito difícil de se compreender se transportarmos para a nossa vida particular. Quantas vezes já recebemos um email ou mensagem de texto onde não compreendemos muito bem o tom utilizado pelo remetente? A linguagem não verbal é extremamente importante para entendermos o contexto da mensagem enviada. Desta forma, a questão é que um diálogo só pode ser considerado verdadeiramente pleno se realizado de forma oral e na presença das partes.

É neste sentido que a oralidade pressupõe a criação de um ambiente propício ao debate, que se traduz na formação de um juízo oral que deve observar, dentre várias, algumas características.

Em primeiro lugar, haverá a predominância da palavra falada, pois como dito, os atos de escrituração não são suficientes para externar todos os nuances do diálogo. Sendo assim, ultrapassada uma primeira fase postulatória, onde invariavelmente haverá a necessidade de juntada de petições e documentos tendentes a preparar o processo para o debate, as etapas que se seguem deverão ser todas travadas em audiências orais, divididas quanto à matéria. ${ }^{58}$

Primeiramente uma audiência de conciliação, onde as partes tentarão firmar algum acordo processual para evitar o litígio, nos casos

aos antecedentes recolhidos pelo fiscal durante a investigação e resguardando a audiência principal com um conjunto de garantias. Em um modelo acusatório, o processo penal é o juízo oral.” (DUCE, Mauricio; BAYTELMAN, Andrés. Litigación penal y juicio oral. Quito: Fondo Justicia e Sociedad. Fundación Esquel - USAID, 2004, p. 16) (tradução livre).

58 Em um sistema de audiências orais, é essencial limitar o contato do juiz com os documentos e informações produzidas na fase da investigação, buscando preservar a sua dimensão intelectual imparcial diante do conflito. É por isso que diversos países que adotaram o sistema acusatório de tendência adversarial investiram na figura do juiz de garantias, responsável pela atuação judicante na fase pré-processual. Sobre isso: MAYA, André Machado. O juiz de garantias no Brasil e nos países latino-americanos: Semelhanças e diferenças determinantes à estruturação democrática do sistema de justiça criminal. In: GOZÁLEZ POSTIGO, Leonel (org). Desafiando a inquisição: Ideias e propostas para a reforma processual penal no Brasil. Santiago de Chile: Centro de Estudios de Justicia de las Américas - CEJA, 2017, p. 277-291, p. 280. 
permitidos pela lei; logo após uma audiência de controle de acusação, ${ }^{59}$ onde as partes irão debater exclusivamente quanto aos elementos e condições para o recebimento da acusação; após, uma audiência preparatória onde serão resolvidos pontos específicos relacionados à questões incidentais, como a definição dos meios de prova, eventual corpo de jurados entre outros; e por fim uma audiência de instrução e julgamento, que permitirá essencialmente o debate central com a apresentação das versões formuladas pelas partes.

Note-se que, independentemente do formato procedimental que será adotado em cada ordenamento, a grande questão é garantir que todo o substrato empírico de fatos e provas seja produzido em audiências orais, ainda que relativo à questões incidentais, de modo que as etapas escriturais sejam unicamente preparatórias, cumpridoras de formalidades. Sendo assim, do que adianta afirmar a oralidade como característica do processo se o recurso de apelação contra a decisão nos tribunais não permite o acesso efetivo das partes? A oralização do julgamento dos recursos com debates em segunda instância para além da leitura dos relatórios e tempos escassos de sustentação é uma necessidade premente para vencer as chamadas falsas oralidades. ${ }^{60}$

É nesse sentido que Binder ensina:

Atualmente, a adoção sem ambiguidades do julgamento oral e público, a utilização em massa da oralidade e publicidade em audiências preliminares (iniciais, incidentais, conciliatórias, de controle geral, de controle de acusação e etc.), bem como a

59 O sistema acusatório de tradição democrática demanda a afirmação de uma estrutura trifásica, possuindo como etapa intermediária entre a investigação criminal e a instrução processual, uma etapa de controle de admissibilidade da acusação, realizada em juízo oral. Sobre isso: PEÑARANDA LÓPEZ, Antonio. El proceso penal en España, Francia, Inglaterra y Estados Unidos: descripción y terminologia. Granada: Comares, 2011, p. 37-42.

${ }^{60}$ Conceito introduzido por Binder para se reportar às diversas roupagens assumidas pelos sistemas inquisitivos, que adotavam mecanismos processuais de essência acusatória de forma distorcida. BINDER, Alberto. Fundamentos para a reforma da justiça penal. In: GOSTINSK, Aline, GONZÁLEZ POSTIGO, Leonel, PRADO, Geraldo (org.). Coleção Reflexões sobre a reforma da justiça penal. Trad. Augusto Jobim do Amaral. Florianópolis: Empório do Direito, 2017. p. 32. 
oralização e incorporação do litígio no processamento recursal (e não o sacramental 'relatório viva voz') aparecem como as novas práticas com maior capacidade de abrir as brechas na fechada tradição inquisitorial. ${ }^{61}$

Desta forma, é necessário que a oralidade se perpetue para além da instrução, encontrando abrigo em todas as etapas do processo, pois, como visto, oralidade não é simplesmente oratória, mas sim construção do caso de forma oral. ${ }^{62}$ Sendo assim, é necessário que as audiências se multipliquem em detrimento da escrituração, que terá um lugar reservado exclusivamente para o cumprimento de formalidades como a qualificação das partes, apresentação inicial da acusação entre outros.

Em segundo lugar, deverá haver a imediação da relação do juiz com as partes e meios de prova, somado à identidade física do julgador, garantindo-se que o debate seja travado na frente do juiz que irá julgar o caso e na presença constante das partes. Essas características evidenciam a necessidade de o julgador estar presente no momento das audiências, utilizando sua capacidade perceptiva em relação ao diálogo das partes, tendo, desta forma, condições de decidir ao final do processo. ${ }^{63}$

Não é exagero dizer que olhar nos olhos de uma pessoa pode nos dar uma percepção completamente diferente do que enxergá-la através de um relato escrito. Desta forma, a presença do juiz e das partes durante a produção de todas as provas em audiência oferece uma gama de percepções que são impassíveis de obtenção de outra forma. É por isso que a presença do réu não pode ser excepcionada por argumentos vagos e imprecisos, assim como a realização de atos por videoconferência não pode ser banalizada. Essas e outras realidades podem alterar profundamente a percepção que se quer fomentar na construção do caso. ${ }^{64}$

${ }^{61}$ BINDER, Alberto. Ob. Cit., p. 34.

${ }^{62}$ CHOUKR, Fauzi. Hassan. Ob. Cit.,.p. 668.

${ }_{63}$ PRADO, Geraldo. Ob. cit., p. 154.

${ }^{64}$ Sobre o interrogatório por videoconferência, expõe André Nicolitt: "Não se pode perder de vista a humanidade. Nenhuma máquina substituirá o conhecimento que se extrai do contato humano. Nenhuma relação através da máquina pode superar ou substituir a relação humana. Quando todos os setores da sociedade buscam a desumanização e o maior implemento da mecanização e maximização de resultados, a justiça, que é a maior das virtudes segundo 
E por fim, a efetividade do diálogo depende da concentração dos atos no tempo, impedindo-se que haja a cisão da audiência em uma infinidade de eventos, dispersando-se a atenção das partes e, especialmente, do juiz, em relação aos pontos travados no debate. ${ }^{65}$ Atualmente é possível enxergarmos uma tendência na divisão das audiências em uma multiplicidade de atos, muitas vezes separados por meses, o que leva a uma invariável degeneração do substrato do diálogo. Seria impossível exigir das partes e do juiz que mantivessem vívidas em suas mentes as impressões produzidas em audiência ocorrida meses atrás.

Dessa forma, a concentração dos atos permite que a prova mantenha de forma mais efetiva a sua virtualidade probatória, já que estará sendo produzida, confrontada e valorada na mesma oportunidade. Ademais, a reunião dos atos permite também um controle mais eficiente pelas partes, pois, se a um testemunho é dada uma valoração desproporcional pelo juiz, a indignação da parte será mais bem observada se realizada de forma imediata do que se feita dias depois. ${ }^{66}$

Sendo assim, após a enunciação das características do juízo oral, é possível observar que o modelo inquisitivo pautado na escrituração considerava desnecessário o contato do juiz com as partes e meios de prova, pois partia do pressuposto de que todo o conhecimento necessário estaria documentado nos autos, de forma técnica e objetiva. Sendo assim, como sustenta Geraldo Prado, "incensada pelo culto à razão, faz supor que este contato é desnecessário: afinal, o que a visão direta da audiência pode ministrar que já não esteja nos autos?"67

Essa era uma visão completamente distorcida do litígio penal e sua forma de decisão sob o ponto de vista democrático, pois, como dito, diante de um debate oral e pessoal, diversos são os elementos que interferem no convencimento do juiz e que são insusceptíveis de escrituração.

Aristóteles, deve dar o exemplo e chamar o homem à sua essência para mostrar que não podemos perder a nossa humanidade ou dela abrir mão." (NICOLITT, André. Manual de processo penal. São Paulo: Revista dos Tribunais, 2016. p. 686).

65 BINDER, Alberto. Introdução ao direito processual penal. Rio de Janeiro: Lumen Juris, 2003. p. 66.

66 Ibidem.

67 PRADO, Geraldo. Ob. cit., p. 157. 
A simples comoção de um réu no interrogatório pode representar o ponto divisor entre a absolvição e a condenação para um jurado no âmbito do júri, sem que isto apareça minimamente mencionado na decisão.

Nesta esteira, valemo-nos novamente de Geraldo Prado, que afirma:

A ênfase na oralidade como componente democrática do processo penal e elemento constitutivo do sistema acusatório tem a ver com o reconhecimento de que os métodos de aplicação do direito, ou melhor, de interpretação das regras jurídicas e de sua efetiva aplicação aos casos concretos, não abrangem toda a atividade intelectual do juiz quando sentencia. Os que conhecem a atividade de decidir têm clara a idéia de que a valoração dos fatos não se expressa de forma completa na sentença. ${ }^{68}$

Ademais, o juízo oral como base do sistema acusatório condiciona toda a atuação desenvolvida no processo, desde a investigação criminal até a fase recursal, ainda que não venha a de fato ocorrer uma audiência oral. E isto se dá porque, tendo em vista se tratar do espaço adequado para o desenvolvimento do debate, é o juízo oral que propicia as maiores chances de convencimento do juiz, representando verdadeiro direito das partes. Sendo assim, a mera eventualidade do juízo oral já condiciona como as partes deverão se portar antes, durante e depois deste, buscando elaborar suas estratégias de acordo. ${ }^{69}$

Neste sentido, ensinam Andrés Baytelman e Mauricio Duce:

Atual ou latente, o juízo oral é o coração de um sistema acusatório e, tanto nas causas que terminam através dele, como naquelas em paira como mera eventualidade, determina o que em todas elas ocorre. Isso acontece porque o julgamento oral é sempre um direito do acusado e, consequentemente, este sempre poderá rejeitar qualquer outra fórmula, através da qual o sistema pretenda restringir seus direitos constitucionais. Então, todos os atores, em todas as

68 PRADO, Geraldo. Ob. cit., p. 155.

69 MONTES CALDERÓN, Ana. JIMÉNEZ MONTES, Fernando. Técnicas del Proceso Oral en el Sistema Penal Acusatorio Colombiano. Manual general para operadores jurídicos. Bogotá: USAID / Programa de Fortalecimiento y Acceso a la Justicia, 2005, p. 98. 
etapas, deverão ter em mente que a eventualidade do julgamento é uma possibilidade sobre a qual ninguém além do acusado tem o controle final e, consequentemente, deverão organizar seu desempenho dentro do procedimento, como se cada causa pudesse eventualmente ir a juízo. ${ }^{70}$

Portanto, toda a atuação no processo tem como base o juízo oral. Os órgãos de persecução na fase da investigação e acusação formularão proposições fáticas e coletarão elementos de prova que sejam sustentáveis em um juízo oral futuro, ainda que este não venha a ocorrer. ${ }^{71}$ Da mesma forma, a defesa em sua interação na fase de investigação ou mesmo na fase postulatória buscará construir uma versão que seja sustentável em um debate oral, visto que do que adianta qualificar uma testemunha na investigação que não poderá depor em audiência no processo em razão de um dever funcional de sigilo?

Ademais, essa perspectiva é importantíssima para fins de controle dos atos processuais, pois a iminência de um juízo oral onde um investigador poderá ser chamado a depor acerca de determinada irregularidade na investigação já é suficiente para coibir ou ao menos diminuir a incidência de tais práticas. ${ }^{72}$ É por isso que a perspectiva do juízo oral funciona como verdadeiro direito fundamental das partes, sendo o único meio constitucionalmente possível de desenvolvimento do litígio penal que assegure com eficácia o direito das partes. ${ }^{73}$

A par da centralidade do juízo oral no sistema acusatório, torna-se necessário agora analisar o modo de agir estratégico que exsurge dessa nova realidade. Uma vez que o debate será travado de forma oral em audiência, é inevitável que a atuação das partes passe primeiramente por um

70 BAYTELMAN, Andrés; DUCE, Mauricio. Ob. cit., p. 16 (tradução livre).

${ }^{71}$ "O desenho e elaboração da estratégia para abordar um caso penal se faz tendo em conta a ocorrência de um juízo oral, que em muitos casos jamais chegará a realizar-se. Isto porque são precisamente seus padrões de admissibilidade, produção e valoração das provas e de fundamentação da sentença os que determinarão o agir dos litigantes, tanto na etapa de investigação do caso, como no próprio juízo em si." (MORENO HOLMAN, Leonardo. Ob. cit., p. 31) (tradução livre).

72 MONTES CALDERÓN, Ana; JIMÉNEZ MONTES, Fernando. Ob. cit., p. 18.

73 BINDER, Alberto. Ob. cit., p. 68. 
estudo para que sejam potencializados os pontos positivos e minimizados os negativos. É isto que será tratado no tópico seguinte.

\section{A INCORPORAÇÃo dA VISÃo ESTRATÉGicA No PROCESSO PENAL}

Para tratar da noção de estratégia como elemento essencial para o desenvolvimento do litígio penal é conveniente apresentar uma imagem muito comum na prática forense. Um advogado, público ou particular, realiza a entrevista privada com um cliente minutos antes de uma audiência preparatória após tomar conhecimento da acusação, informando a ele que naquele momento irá se limitar a negar as acusações de forma genérica. Iniciada a audiência, o juiz responsável passa a palavra à acusação que pergunta diretamente ao réu se seria culpado das imputações e o mesmo, contrariando as expectativas do advogado, lhe responde que sim.

Note-se que há na figura ilustrativa tratada acima, mais comum na prática do que se gostaria de admitir, mais do que uma falta de preparo do defensor, conclusão quase que intuitiva, mas sim uma falta de pensamento estratégico em relação ao processo. Ou seja, em nenhum momento o defensor buscou definir uma linha de desenvolvimento estratégico, ainda que parcial ou temporária, se limitando a pensar de forma imediata e formalista. Ainda mais grave, deixou de questionar e incorporar a visão do réu, maior interessado na causa, tornando a derrota processual iminente.

Sendo assim, quando se pensa em um processo que será desenvolvido a partir do diálogo entre as partes, sobretudo em audiências orais, a noção de estratégia decorre como uma conclusão imediata. ${ }^{74}$

O fato é que a noção de estratégia sempre incomodou a nossa cultura jurídica tradicional, pautada em uma noção inquisitiva de que o processo serviria como instrumento de apuração da verdade. Para essa concepção, como o juízo poderia ser uma questão estratégica? Ou o autor cometeu o fato ou não cometeu. A ideia de estratégia processual soava como algo pejorativo, sendo visto como uma forma de tentar ludibriar

74 MORENO HOLMAN, Ob. Cit., p. 31. 
o juiz em sua missão de averiguação dos fatos. ${ }^{75} \mathrm{O}$ advogado estrategista era tido como um profissional antiético, que buscava mascarar a verdade induzindo testemunhas ou omitindo provas, ${ }^{76} \mathrm{da}$ mesma forma o investigador com noções de estratégia era logo associado a um profissional violador de direitos.

A grande questão é que, como visto, a verdade é relativa e reside no passado. Ainda que se trate de um caso simples, sempre existirão determinadas zonas de verdade que não se permitirão conhecer, tornando, desta forma, o juízo penal um conjunto de versões fragmentadas, parciais e distintas que apresentam, a seu modo, apenas uma faceta da verdade. Desta forma, a apresentação dessas versões demanda um emprego estratégico garantindo à parte que, com aquela visão da verdade, seja possível obter o êxito processual. ${ }^{77}$

Para a concepção inquisitiva, as provas eram tidas como elementos neutros que falavam por si próprias, cabendo ao juiz desvendar a verdade por de trás. Todavia, sob a perspectiva adversarial do conflito, as provas não falam absolutamente nada se dissociadas de uma versão ou de um contexto proposto. ${ }^{78}$ Sendo assim, um revólver não passa de um revólver, de modo que essa informação não é suficiente para vinculá-lo a qualquer pretensão. Porém, ao contrário, se a apresentação desse elemento de prova

75 BINDER, Alberto. La fuerza de la oralidad. 2012. Publicado por INECIP Instituto de Estudios Comparados en Ciencias Penales y Sociales. Disponível em: <http://inecip.org/wp-content/uploads/INECIP-Binder-La-fuerza-de-la oralidad.pdf>. Acesso em: 16 jan. 2018, p. 4

76 Na concepção inquisitiva é comum conceber o advogado defensivo atuante como um obstáculo, frequentemente rechaçado por juízes, promotores e delegados, quando muito criminalizados. Sobre o tema, há importante reflexão de Geraldo Prado: “A incriminação da defesa criminal é ilegal. É também, fundamentalmente, uma violação ao estado de direito. Flerta com o autoritarismo e namora firme o moralismo salvacionista. É de se esperar que a justiça não lhe dê ouvidos... por outro lado não se deve negligenciar a pressão da comunicação social e os propósitos políticos ocultos que sempre estiveram a lhe inspirar." (PRADO, Geraldo. Obstrução da injustiça: a irrenunciável combatividade da defesa criminal. Disponível em: <http://justificando.cartacapital. com.br/2017/10/25/obstrucao-de-injustica-irrenunciavel-combatividade-da-defesa-criminal/.> Acesso em: 09 nov. 2017).

77 BAYTELMAN, Andrés. DUCE, Mauricio. Ob. cit., p. 30.

78 MORENO HOLMAN, Ob. Cit., p. 24. 
é associado a um relato de que o revólver estaria na posse de determinada pessoa, somando-se outras provas que venham a suprir o standard exigido, ${ }^{79}$ é possível dotá-la de carga probatória para, por exemplo, imputar um crime de porte ilegal de arma de fogo a determinada pessoa.

Neste sentido, quando se aponta que a forma de litigar em juízo passa por uma noção de estratégia, não se está defendendo uma receita para enganar o juízo a partir de versões cativantes, mas sim se defende que o tribunal tenha alguma chance de decidir o litígio com base nas informações sobre o que de fato aconteceu. Assim sendo, demanda-se das partes que apresentem versões suficientemente claras, coerentes e comprometidas com os fatos e provas, capazes de transmitir ao julgador a convicção de que se trata da versão mais fidedigna e que, desta forma, merece ser acolhida. ${ }^{80}$

É desta forma que a noção de estratégica exsurge como uma realidade diante da perspectiva do conflito. É como ensina Moreno Holman, "as técnicas de litigância são o melhor instrumento mediante o qual o litigante pode transmitir uma mensagem ao julgador de uma maneira eficiente e eficaz a fim de lograr na formação de sua convicção." ${ }^{81}$

Assim sendo, pode-se dizer que a noção de estratégia processual não é exclusiva do sistema adversarial a ponto de ser incompatível com sistemas mistos, sendo uma realidade presente em qualquer sistema de justiça que congregue um mínimo de debate processual entre as partes. Estar minimamente preparado para o diálogo, antevendo perguntas ou preparando respostas, já representa uma dimensão básica de preparação metodológica para o caso, especialmente em um contexto de relações sociais e práticas criminais cada vez mais rebuscadas e complexas que tornam o emprego retórico dos elementos de prova quase que inevitável.

É importante ressaltar desde já que a noção de atuação adversarial, notadamente de forma estratégica, exige a afirmação de um equilíbrio entre as partes, de modo que a acusação e defesa deverão estar em

79 NICOLITT, André; BARILLI, Raphael Jorge de Castilho. Standards de prova no Direito - debate sobre a súmula 70 do Tribunal de Justiça do Rio de Janeiro. Boletim do IBCcrim, São Paulo, a. 26, n. 302, 2018, p. 6-9. p. 6.

${ }^{81}$ MORENO HOLMAN, Ob. Cit., p. 27. Tradução livre. 
igualdade de condições para apresentarem suas versões. Nesse sentido, será imprescindível que o ordenamento processual disponha de regras voltadas à paridade de armas, evocada como premissa fundamental de um julgamento justo. ${ }^{82}$

Basicamente se pode dividir essas regras em duas grandes categorias jurídicas. De um lado estariam aquelas voltadas ao controle dos comportamentos processuais das partes e do juiz, ligadas às noções de ética e boa-fé, e de outro lado estariam as normas voltadas à legalidade das provas, chamadas no direito anglo-saxão de exclusionary rules. ${ }^{83}$

O chamado Discovery seria justamente a confluência dessas duas grandes categorias, buscando assegurar o equilíbrio entre as partes e a produção de um conhecimento válido do ponto de vista da verificabilidade com os fatos. Nesse sentido, as medidas de descoberta das fontes da prova buscam providenciar de forma eficaz que uma das partes tome conhecimento das provas que a outra pretende produzir e de como as obteve, podendo controlar sua legalidade, utilizando-as de forma adequada ao seu próprio relato. ${ }^{84}$

O funcionamento das regras de Discovery depende da estruturação do procedimento penal, devendo viabilizar o controle dialético pelas partes acerca da atividade probatória do adversário, além do destacado papel do juiz na fiscalização da regularidade procedimental, sem se arvorar na atividade probatória em si, de modo que a jurisdição seja concebida como tutela do ordenamento jurídico. A concepção de litigância estratégica depende, pois, da afirmação de um espaço digno onde as partes possam atuar de forma equilibrada e eticamente aceitável, contribuindo para a produção do conhecimento, sem que possa, portanto, ser associada a qualquer meio de atuação indevida que busque enganar o juiz ou afastá-lo da verdade.

Quanto ao momento de atuação estratégica, torna-se relativamente fácil enxergar a necessidade de desenvolvimento estratégico quando pensado

\footnotetext{
82 PRADO, Geraldo. Prova penal e sistema de controles epistêmicos: a quebra da cadeia de custódia das provas obtidas por métodos ocultos. São Paulo: Marcial Pons, 2014, p. 49.

83 Ibidem, p. 52.

84 Ibidem, idem.
} 
o juízo oral. A forma como uma testemunha será inquirida ou se determinada mídia eletrônica será ou não reproduzida diante do julgador demonstra a importância de se ter um pensamento estratégico durante a audiência, pois, por ser o centro do julgamento, um descuido sequer como o mencionado no exemplo inicial pode representar a derrota processual. Sendo assim, o momento da exposição oral é sem dúvida o epicentro de todo o planejamento. ${ }^{85}$

Entretanto, isso não quer dizer que não haja planejamento em outros momentos do processo. De fato, desde o primeiro contato com os autos, as partes devem estruturar a sua atuação por meio de considerações estratégicas, tendentes a determinado objetivo. Isto garantirá um melhor aproveitamento de cada etapa processual, elaborando-se as versões de forma cuidadosa, priorizando-se os pontos fortes e eliminando-se os pontos fracos, garantindo que a parte chegue mais bem preparada ao juízo oral. ${ }^{86}$

Ademais, essa necessidade torna-se ainda mais evidente em relação aos órgãos encarregados da persecução penal, posto que desde o primeiro momento da investigação criminal, iniciada seja por meio de uma prisão em flagrante, seja pela comunicação da vítima, o titular da investigação criminal deverá conduzir os atos de modo a viabilizar determinada versão sobre os fatos que será apresentada em um juízo oral futuro. Dessa forma, é possível que durante o inquérito haja diversas histórias possíveis, todavia, a medida em que a investigação venha a progredir, estas versões serão submetidas a testes de verificação e consistência, até que se chegue a uma hipótese mais provável. ${ }^{87}$

Sendo assim, a noção de estratégia é que irá conferir ao investigador, ou mesmo ao defensor em sua investigação privada, a compreensão de que se deve atuar desde o primeiro momento do litígio de maneira planejada, formulando-se as proposições fáticas de acordo com a história que se deseja contar, coletando-se os elementos de prova que corroborem a sua visão acerca do litígio. Sendo assim, a dinâmica do processo penal exige das partes que se passe por cada etapa processual com uma estratégia, desenho ou planejamento metodológico, aumentando-se, desta forma, as chances de êxito. ${ }^{88}$

\footnotetext{
85 BENAVENTE CHORRES, Hesbert. Ob. Cit., p. 81.

${ }^{86}$ MORENO HOLMAN, Ob. Cit., p. 29.

87 Ibidem, p. 30.

88 BENAVENTE CHORRES, Hesbert. Ob. Cit., p. 393.
} 
Como deixou-se transparecer, a versão do caso que será afirmada no processo não nasce pronta e acabada, carecendo de um desenvolvimento por meio de testes de verificação e consistência à medida em que os elementos de prova são coletados. Desta forma, se as investigações de um crime de homicídio apontam para determinado suspeito que durante a fase preliminar apresenta um álibi consistente que o retira da cena do crime, será necessário que o relato se modifique para, por exemplo, conceber uma possível autoria mediata, permitindo, desta forma, a sobrevivência do conjunto até então produzido.

É por isso que uma das principais características do pensamento estratégico no processo penal é a sua adaptabilidade, permitindo que se construa com base em elementos modificáveis segundo a evolução do caso, o que garantirá sua longevidade. ${ }^{89}$ Ademais, é possível, inclusive, conceber-se mais de uma versão sobre o caso, revelando-se uma ou outra a depender do momento processual.

Neste sentido, ensina Kimberly A. Thomas:

Em outras palavras, a teoria do caso é fluida e contextual. Deve ser entendida como relevante no somente para o julgamento, mas também durante as negociações, fase preliminar e ainda no trabalho de transação. Ademais, uma determinada situação legal pode apresentar mais de uma "teoria do caso". Acordos de barganha processual podem envolver uma teoria do caso baseada em temas acerca da culpabilidade e remorso, enquanto argumentações futuras em audiência podem desenvolver um tema de excesso policial, e após no julgamento pode-se focar em uma teoria do caso diferente que vise diminuir a culpabilidade do acusado. Advogados cuidadosos irão desenvolver cada teoria do caso com um olho nas demais que serão apresentadas durante o caso para evitar contradições que minem a credibilidade da teoria do caso. No entanto, dentro desta limitação, o advogado e seu cliente devem crer que cada estágio do processo tem um objetivo distinto e uma teoria do caso específica, e algumas vezes distinta deve ser desenvolvida para atingir cada objetivo. . ${ }^{90}$

89 MORENO HOLMAN, Ob. Cit., p. 36.

90 THOMAS, Kimberly A. Sentencing: Where Case Theory and the Client Meet. Michagan, Clinical L. Rev., v. 15, n. 1, 2008, p. 187-210. p. 190 (tradução livre). 
Particularmente em relação à defesa, duas recomendações são necessárias. Em primeiro lugar, a adaptabilidade nos parece ainda mais relevante quando pensamos na defesa, visto que muitas vezes busca-se adotar uma postura reativa, ou seja, priorizando reagir às investidas da acusação. Desta forma, é muito comum haver situações que possam surpreender o advogado defensivo, devendo estar sempre preparado para modificar o seu relato a medida em que tais situações ocorrem. ${ }^{91}$

Além disso, é fundamental que se incorpore à estratégia de defesa a visão do réu. Pois, apesar de parecer óbvio, muitas vezes os advogados de defesa simplesmente impõem a ideia que acham mais relevante acerca do caso sob o ponto de vista técnico sem ao menos considerar as expectativas do seu cliente, dando margem a situações como a cena retratada linhas atrás. Sendo assim, o diálogo franco entre advogado de defesa e cliente irá resultar em uma versão sobre o caso que reflita as pretensões técnicas do advogado, mas também as expectativas emocionais do cliente, ganhando em solidez e credibilidade. ${ }^{92}$

Por fim, cumpre ressaltar a necessidade de um desenvolvimento metodológico e estruturado no tratamento estratégico do processo. Por mais que muitas vezes apostemos no faro ou intuição, muito comum para advogados e investigadores experientes, nada substitui a organização quando o assunto é ação de resultado. Não só ajuda a minimizar os erros e ações desnecessárias, como também auxilia a aumentar o rendimento. É por isso que a atuação estratégica não pode ser deixada ao improviso, exigindo um desenvolvimento ordenado, com estrutura, constantemente avaliando riscos e resultados.

É como ensinam Andrés Baytelman e Mauricio Duce:

O juízo oral é vertiginoso e não reserva nenhuma piedade para os advogados que não saibam exatamente o que devem fazer no momento oportuno. Confiar e abandonar-se à intuição e ao talento é um erro, que em geral acaba em uma sentença desfavorável para o advogado que confiou que poderia improvisar sobre o procedimento. Grande parte da "arte” do litígio, em um juízo oral, consiste em técnicas que podem ser aprendidas do mesmo que se

\footnotetext{
91 MORENO HOLMAN, Ob. Cit., p. 37.

92 THOMAS, Kimberly A. Ob. Cit., p. 193.
} 
aprende qualquer outra disciplina. É certo que seus resultados nem sempre gozam da mesma precisão, entretanto isso não desmente o fato de que a arte de ser um bom litigante possa ser adquirida e transmitida. Conhecer e utilizar essas técnicas nos proporcionará uma base sólida para formular as decisões intuitivas que o juízo oral, de todo modo, demandará de nós. ${ }^{93}$

\section{Considerações Finais}

Diante de tudo que foi exposto, pretendeu-se com essa breve exposição apontar inicialmente para o descompasso que a concepção punitivista, pautada por uma epistemologia inquisitiva e autoritária, produz em relação ao diálogo entre as partes. Para este modelo, o debate oral é algo desnecessário, pois não há nada que possa ser trazido através deste que já não esteja nos autos, e que deve ser evitado, pautando-se o processo por meio de procedimentos escritos, tomando a formalidade e a burocratização como verdadeiras garantias de racionalidade processual.

Apesar de ser essa a realidade da maioria dos países da América Latina, há hoje uma forte tendência em superar essa conjuntura, que passa necessariamente pela afirmação da oralidade como centro metodológico do sistema acusatório. ${ }^{94}$ Disso resulta a tendência adversarial de ser um processo pautado pelo litígio entre as partes.

A noção de estratégia processual deixa de ser algo pejorativo, associado à práticas de encobrimento da verdade para ser uma realidade processual de preparação metodológica. Como visto, em sendo a verdade insusceptível de plena retratação, eis que reside no passado, o juízo penal acaba por se tornar um conjunto de versões em conflito, que deverão ser elaboradas de forma ordenada pelas partes, devendo apresentar uma relação de verificabilidade com os fatos para que possam ser sustentadas e assumidas como razão de decidir pelo juiz.

93 BAYTELMAN, Andrés; DUCE, Mauricio. Ob. cit., p. 32 (tradução livre).

BINDER, Alberto. La fuerza de la oralidad. 2012. Publicado por INECIP - Instituto de Estudios Comparados en Ciencias Penales y Sociales. Disponível em: <http://inecip.org/wp-content/uploads/INECIP-Binder-La-fuerza-de-la oralidad.pdf >. Acesso em: 16 jan. 2018, p. 6. 
Nesse contexto, a preparação estratégica é essencial para a formação de tais versões, não representando qualquer meio de ludibriar ou enganar o julgador. Uma vez que possui como premissas o equilíbrio entre as partes e a atuação ética, devidamente assegurados por regras de comportamento processual e controle dos meios de prova, a ser realizado tanto pelo juiz, quanto pelas partes, a atuação estratégica não representa qualquer falta de compromisso com a verdade. O desenvolvimento estratégico, que deve ser observado desde o primeiro contato com os autos e não só nas audiências, representa uma ferramenta essencial em um contexto de litigância processual moderno, sobretudo realizado de forma oral.

Para a afirmação de tal modelo, alguns apontamentos são importantes:

- Em primeiro lugar, a oralidade não representa oratória, aludindo-se à suposta habilidade que as partes acreditam ter mais ou menos que outras. O que se pretende é a afirmação de um novo sistema de administração da justiça, que passa da simples gerência de petições escriturais a uma administração pautada no litígio.

- A construção do caso passa a se dar de forma essencialmente oral, ou seja, a produção dos elementos empíricos (fatos e provas) obrigatoriamente se dá em audiência.

- Essa nova realidade demandará necessariamente a multiplicação de audiências em nível normativo, divididas em razão da matéria e do momento processual (p.ex., audiência inicial referente ao recebimento da denúncia; audiência de conciliação; audiência de instrução entre outras), sem esquecer dos princípios da concentração, imediação e identidade física do juiz.

- A noção de litigância estratégia deve ser entendida como planejamento metodológico e não como mera intuição ou habilidade. Sendo assim, exige-se uma atuação estruturada ao longo de todo o processo, tendo como objetivo final a apresentação de uma versão acerca dos fatos no processo.

- Por fim, é impensável assumir essas novas características sem um aprofundamento na formação dos profissionais que 
atuam no processo. ${ }^{95}$ Desta forma, será necessário fomentar a elaboração de manuais de estratégia processual, além de laboratórios de argumentação e persuasão nas universidades, dando condição para que esta finalidade de resolução de litígios se torne algo concreto e efetivo.

\section{REFERÊNCIAS}

BADARÓ, Gustavo H. Processo penal. São Paulo: Editora Revista dos Tribunais, 2017. BENAVENTE CHORRES, Hesbert. La aplicación de la teoría del caso y la teoría del delito en el proceso penal acusatorio. Barcelona: Bosh Editor, 2011.

BENAVENTE CHORRES, Hesbert. La construcción de los interrogatorios desde la teoría del caso. Barcelona: Bosh Editor, 2015.

BETEGÓN, Jerónimo, DE PÁRAMO, Juan Ramón, LAPORTA, Francisco J., SANCHÍs, Luis Prieto (org). Constituición y derechos fundamentales. Madrid: Secretaría General Técnica. Centro de estudios políticos y constitucionales, 2004.

BINDER, Alberto. Introdução ao direito processual penal. Rio de Janeiro: Lumen Juris, 2003.

BINDER, Alberto. Derecho procesal penal. Buenos Aires: Ad-Hoc, 2013.

BINDER, Alberto. Fundamentos para a reforma da justiça penal. In: GOSTINSK, Aline, GONZÁLEZ POSTIGO, Leonel, PRADO, Geraldo (org.). Coleção Reflexões sobre a reforma da justiça penal. Trad. Augusto Jobim do Amaral. Florianópolis-SC: Empório do Direito, 2017.

BINDER, Alberto. La fuerza de la oralidad. 2012. Publicado por INECIP - Instituto de Estudios Comparados en Ciencias Penales y Sociales. Disponível em: <http:// inecip.org/wp-content/uploads/INECIP-Binder-La-fuerza-de-la oralidad.pdf $>$. Acesso em: 16 jan. 2018.

95 Sobre o desenvolvimento de estudos no campo da litigância oral, há interessante experiência na Escuela de Derecho da Universidad Diego Portales no Chile, onde os alunos recebem treinamento e instrução acerca do conjunto de técnicas que devem ser exploradas no desenvolvimento do juízo oral, tais como: abertura do juízo oral e apresentação do caso, preparação das testemunhas, exame e contra-exame das testemunhas e peritos, alegações finais entre outros. O referido programa se consolidou como um marco da diplomação que a escola oferece, "Reforma Procesal Penal, Juicio Oral y Litigación." Relatado em: BAYTELMAN, Andrés; DUCE, Mauricio. Litigación penal en juicios orales. Santiago de Chile: Universidad Diego Portales. RiL editores, 2000. p. 14. 
CAVISE, Leonard L. The transition from the inquisitorial to the accusatorial system of trial procedure: Why some Latin American lawyers hesitate. Disponível em: <http://biblioteca.cejamericas.org/bitstream/handle/2015/3622/cavise.pdf?sequence=1\&isAllowed=y.>. Acesso em: 20 jan. 2018.

CHOUKR, Fauzi. Hassan. Iniciação ao processo penal. Florianópolis, SP: Empório do Direito, 2017.

CHOUKR, Fauzi. Hassan. Garantias Constitucionais na investigação criminal. Rio de Janeiro: Lumen Juris, 2001.

COUTINHO, Jacinto Nelson de Miranda (org.). Crítica à teoria geral do processo penal. Rio de Janeiro: Renovar, 2001.

DUCE, Mauricio; BAYTELMAN, Andrés. Litigación penal y juicio oral. Quito: Fondo Justicia e Sociedad. Fundación Esquel - USAID, 2004.

DUCE, Mauricio; BAYTELMAN, Andrés. Litigación penal en juicios orales. Santiago de Chile: Universidad Diego Portales. RiL editores, 2000.

DUCE, Mauricio; RIEGO, Cristián. Desafios del Ministério Público fiscal en América Latina. Santiago de Chile: Centro de Estudios de Justicia de las Américas - CEJA, 2005.

DWORKIN, Ronald. O império do direito. São Paulo: Martins Fontes, 1999.

FERRAJOLI, Luigi. Direito e razão: Teoria do garantismo penal. São Paulo: Revista dos Tribunais, 2002.

GONZÁLEZ LAGIER, Daniel. Quaestio facti: Ensayos sobre prueba, causalidad y acción. Disponível em: <http://www.academia.edu/24429680/Quaestio_facti_Ensayos_sobre_prueba_causalidad_y_acci\%C3\%B3n.> Acesso em: 20 jan. 2018. GOZÁLEZ POSTIGO, Leonel (org). Desafiando a inquisição: Ideias e propostas para a reforma processual penal no Brasil. Santiago de Chile: Centro de Estudios de Justicia de las Américas - CEJA, 2017.

HABERMAS, Junger. Conhecimento e interesse. Rio de Janeiro: Zahar editores, 1982. HASSEMER, Winfried. Fundamentos del derecho penal. Barcelona: Bosh, 1984.

KHALED, Salah H. A busca da verdade no processo penal para além da ambição inquisitorial. Minas Gerais: Letramento: Casa do Direito, 2016.

KNIJNIK, Danilo. Prova nos juízos cível, penal e tributário. Rio de Janeiro: Forense, 2007.

LOPES JR., Aury. Direito processual penal. São Paulo: Saraiva, 2014.

LOPES JR., Aury. Sistemas de investigação preliminar no processo penal. Rio de Janeiro: Lumen Juris, 2001.

MAIER, Julio B. J. El procedimento abreviado. Buenos Aires: Del Puerto, 2005. 
MALAN, Digo R. Direito ao confronto no processo penal. Rio de Janeiro: Lumen Juris, 2009.

MORENO HOLMAN, Leonardo. Teoría del caso. Buenos Aires: Editora Didot, 2012. MONTES CALDERÓN, Ana. JIMÉNEZ MONTES, Fernando. Técnicas del proceso oral en el sistema penal acusatorio colombiano. Manual general para operadores jurídicos. Bogotá: USAID / Programa de Fortalecimiento y Acceso a la Justicia, 2005.

NICOLITT, André. Manual de processo penal. São Paulo: Revista dos Tribunais, 2016.

NICOLITT, André; BARILLI, Raphael Jorge de Castilho. Standards de prova no Direito - debate sobre a súmula 70 do Tribunal de Justiça do Rio de Janeiro. Boletim do IBCcrim, São Paulo, Ano. 26. N 302, 2018, p. 6-9.

PEÑARANDA LÓPEZ, Antonio. El proceso penal en España, Francia, Inglaterra y Estados Unidos: descripción y terminologia. Granada: Comares, 2011.

PRADO, Geraldo. Sistema acusatório. A conformidade constitucional das leis processuais penais. Rio de Janeiro: Lumen Juris, 2006.

PRADO, Geraldo. Prova penal e sistema de controles epistêmicos: a quebra da cadeia de custódia das provas obtidas por métodos ocultos. São Paulo: Marcial Pons, 2014.

PRADO, Geraldo. Obstrução da injustiça: a irrenunciável combatividade da defesa criminal. Disponível em: <http://justificando.cartacapital.com.br/2017/10/25/ obstrucao-de-injustica-irrenunciavel-combatividade-da-defesa-criminal/.> Acessado em: 09.11.2017.

RUA, Gonzalo e GONZALEZ, Leonel. Las salidas alternativas al proceso penal en América Latina. Una visión sobre su regulación normativa y propuestas de cambio. Revista Sistemas Judiciales, Santiago de Chile, Ano 16, N. 20, 2017, p. 99-124.

SENS, Sheila C. da S. A teoria interpretativa de Dworkin: Um modelo construtivo. Revista da Faculdade Mineira de Direito. v. 16, n. 31, p.119-147, 2013.

TARUFFO, Michele. A prova. São Paulo: Marcial Pons, 2014.

TARUFFO, Michele. La prueba de los hechos. Madrid: Editorial Trota, 2002.

TARUFFO, Michele. Modelli di prova e di procedimento probatorio. Rivista di Diritto Processuale, Padova, v.2, XLV, 1990, pp. 420-448.

THOMAS, Kimberly A. Sentencing: Where Case Theory and the Client Meet. University of Michigan Law School Repository. Michagan, Clinical L. Rev. 15, n. 1, 2008, p. 187-210.

VERMEULE, Adrian. Judging under Uncertainty: An institucional theory of legal interpretation. London: Harvard University Press, 2006.

WEBER, Max. Metodologia das Ciências Sociais. São Paulo, Campinas: Ed. Unicamp, 1993. 


\section{Informações adicionais e declarações dos autores (integridade científica)}

Agradecimentos (acknowledgement): Agradeço ao estimado professor Flávio Mirza Maduro e a todo o Programa de Pós-Graduação em Direito Processual da UERJ, pela contribuição com os debates onde foram tratados vários dos temas desenvolvidos neste trabalho; e ao estimado professor Geraldo Prado pela revisão crítica do manuscrito, além das inúmeras orientações que possibilitaram a conclusão do trabalho.

Declaração de conflito de interesses (conflict of interest declaration): o autor confirma que não há conflitos de interesse na realização das pesquisas expostas e na redação deste artigo.

Declaração de autoria e especificação das contribuições (declaration of authorship): todas e somente as pessoas que atendem os requisitos de autoria deste artigo estão listadas como autores; todos os coautores se responsabilizam integralmente por este trabalho em sua totalidade.

Declaração de ineditismo e originalidade (declaration of originality): o autor assegura que o texto aqui publicado não foi divulgado anteriormente em outro meio e que futura republicação somente se realizará com a indicação expressa da referência desta publicação original; também atesta que não há plágio de terceiros ou autoplágio. 
Dados do processo editorial

(http://www.ibraspp.com.br/revista/index.php/RBDPP/about/editorialPolicies)

- Recebido em: 27/03/2018

Equipe editorial envolvida

- Controle preliminar e verificação de plágio:

- Editor-chefe: 1 (VGV)

- Avaliação 1: 17/04/2018

- Avaliação 2: 22/04/2018

- Avaliação 3: 30/04/2018

- Decisão editorial preliminar: 01/05/2018

- Retorno rodada de correções 1: 15/05/2018

- Editora-associada: 1 (LBW)

- Editor-assistente: 1 (ADR)

- Revisores: 3

- Decisão editorial preliminar 2: 20/05/2018

- Retorno rodada de correções 2: 21/05/2018

- Decisão editorial final: 22/05/2018

\section{COMO CITAR ESTE ARTIGO:}

BARILLI, Raphael Jorge de Castilho. A centralidade do juízo oral no Sistema Acusatório: uma visão estratégica acerca do caso penal. Revista Brasileira de Direito Processual Penal, Porto Alegre, vol. 4, n. 2, p. 669-705, mai./ago. 2018. https://doi.org/10.22197/rbdpp.v4i2.150

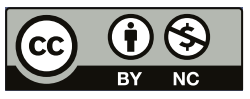

Esta obra está licenciada com uma Licença Creative Commons Atribuição-NãoComercial 4.0 Internacional. 